\title{
Constipation Problem in Nursing Students and Effectiveness of Interventions used by them for its Management
}

\author{
Melike Demir Dogan* \\ Faculty of Health Sciences, Gümüșhane University, Turkey
}

*Corresponding author: Melike Demir Dogan, Gümüşhane Üniversitesi Sağlik Bilimleri Fakültesi, Bağlarbaşı Mahallesi 29100 / Gümüşhane, Turkey.

Received Date: November 14, 2018

Published Date: November 28, 2018

\section{Abstract}

Aim: The purpose of this cross-sectional study is to determine the prevalence rate of constipation in nursing students and the effectiveness of nursing interventions used by them to manage constipation in their own lives.

Material and Method: 232 students who agreed to participate in the study were included in the sample. In the study, the data were collected in November 2017 using the Constipation Evaluation Scale and a questionnaire prepared by reviewing the relevant literature.

Results: While $87.5 \%$ of the students stated that they had no constipation during the study, $77.6 \%$ stated that they experienced constipation before. The students, who stated that they did not have constipation at that time, consumed pulpy food and these foods were effective [ $\left.\chi^{2}=10.99 ; \mathrm{p}=0.001\right]$. The students who stated that they had no constipation at that time drank at least 2 liters of water a day and this was effective $\left[\chi^{2}=15.89 ; \mathrm{p}<0.001\right]$.

Conclusion: As a result of this study, it was observed that in the management of the constipation, the consumption of pulpy food, water consumption of 2 liters per day and exercise were effective nursing interventions that can be applied to individuals.

Keywords: Work Motivation; Factors; Nurse

\section{Introduction}

Constipation is a condition in which an individual feels an abnormality in her or his bowel functions and also experiences less defecation and feels the symptoms of distress, strain, and swelling in the lower abdominal region [1].

The studies have reported that the prevalence of constipation varies between $2.6 \%$ and $30.7 \%$ [2-5]. In another study, it was reported that the prevalence of constipation was $37.2 \%$ for women and $10.2 \%$ for men. In the same study, it was stated that the prevalence of constipation increased with increasing age [6]. In a study conducted in Turkey, it was reported that the prevalence of constipation was $20 \%$ and $73 \%$ of individuals constituting this rate were women and $30 \%$ were 60 years old and over [7]. In another study which was conducted in 20 provinces in Turkey and included $52 \%$ of the country's population, the prevalence of constipation was found to be $8.3 \%$ [8].
Constipation is encountered as an important healthcare problem because it impairs quality of life, causes the loss of energy, increases healthcare expenditures, and is prevalent with other medical problems $[9,10]$. As required by nursing practices; nurses play an important role in identifying constipation, determining the factors causing constipation, and developing effective coping strategies [11]. A detailed history to be received by nurses while evaluating constipation will shed light on practices for the solution of constipation [12]. Nurses, who play an important role in both care and treatment, are expected to comprehend the importance of promoting health, develop appropriate health behaviors, and set an example to society with these behaviors that they apply in their own lives as from their student years [13-15]. As the health team members of the future; nursing students are primarily required to realize the presence of constipation in themselves and 
find a solution [16]. In Turkey, there is a limited number of studies evaluating the prevalence of constipation in nursing students and no study evaluating the constipation experience of nursing students in their own lives and nursing interventions that they apply has been found. Therefore, this cross-sectional study was conducted to determine the prevalence of constipation in nursing students and the effectiveness of nursing interventions applied by them to manage constipation in their own lives.

\section{Material and Method}

The purpose of this cross-sectional study was to determine the prevalence of constipation in nursing students and the effectiveness of nursing interventions used by them to manage constipation in their own lives. The population of this study conducted at a university in the Black Sea region consisted of 350 students studying in the department of nursing. The first-year students were not included in the study because they had just been learning nursing interventions and nursing. 232 students who agreed to participate in the study were included in the sample of the study. The data in the study were collected using a questionnaire which was prepared by examining the relevant literature, and Constipation Evaluation Scale in November, 2017.

\section{Questionnaire}

This form involves 11 questions examining socio-demographic characteristics. In addition, the students were asked whether or not they used 12 nursing interventions, used in constipation management, in their own lives and whether or not the interventions used by them were effective.

\section{Constipation Assestment Scale (CAS)}

The Constipation Assestment Scale whose Turkish validity and reliability study was conducted by Demir Doğan and Aktuğ has 8 items and each item is scored between 0-2 points. Total score of the scale is obtained by summing the scores obtained from all items. The scores to be obtained from the scale vary between 0 [no constipation] -16 [presence of severe constipation] points and as the score increases, the severity of constipation increases. The Cronbach's Alpha value of the scale is 0.784 [17]. In this study, on the other and, the Cronbach's Alpha value of the scale was found as 0.861 . After receiving necessary permissions in the study, the students who participated in the study were informed and their verbal consent was received. The data were statistically evaluated using percentage, mean, and standard deviation. The significance was evaluated using t test, chi-square test, and Pearson's correlation analysis.

\section{Result}

Age average of the students was $20.73 \pm 1.50$ years and $73.3 \%$ were female students. It was observed that a great majority of the participants were single (98.3\%) and unemployed (96.1\%). Among the students; $39.7 \%$ were the second-year students, $34.5 \%$ were the third-year students, and $25.9 \%$ were the fourth-year students. A great majority of the students (74.6\%) stated that they stayed in a dormitory (Table 1).

It was observed that $90.1 \%$ of the students had no health problem and the students who had health problems suffered from asthma, anemia, renal failure, epilepsy, allergy, scoliosis, arrythmia, and gastritis. It was also determined that majority of the students did not use cigarettes (82.8\%) and alcohol (89.7\%) (Table 1). While $87.5 \%$ of the students stated that they had no constipation during the study, $77.6 \%$ stated that they experienced constipation before. The mean score obtained from the Constipation Assestment Scale was determined as $2.91 \pm 3.18$ (Table 1 ).

Table 1: Socio-Demographic Characteristics of the Students.

\begin{tabular}{|c|c|c|}
\hline & Number & $\%$ \\
\hline Age & \multicolumn{2}{|c|}{$20.73 \pm 1.50$} \\
\hline Gender & & \\
\hline Female & 170 & 73.3 \\
\hline Male & 62 & 26.7 \\
\hline \multicolumn{3}{|l|}{ Marital Status } \\
\hline Married & 4 & 1.7 \\
\hline Single & 228 & 98.3 \\
\hline \multicolumn{3}{|l|}{ Class } \\
\hline 2 & 92 & 39.7 \\
\hline 3 & 80 & 34.5 \\
\hline 4 & 60 & 25.9 \\
\hline \multicolumn{3}{|l|}{ Working Condition } \\
\hline Employed & 9 & $3, .9$ \\
\hline Unemployed & 223 & 96.1 \\
\hline \multicolumn{3}{|l|}{ Presence of a Health Problem } \\
\hline Yes* & 23 & 9.9 \\
\hline No & 209 & 90.1 \\
\hline \multicolumn{3}{|l|}{ Residence Place } \\
\hline With family & 10 & 4.3 \\
\hline In a dormitory & 173 & 74.6 \\
\hline At home with friends & 43 & 18.5 \\
\hline With a relative & 2 & 0.9 \\
\hline At home alone & 4 & 1.7 \\
\hline \multicolumn{3}{|l|}{ Smoking } \\
\hline Yes & 36 & 15.5 \\
\hline No & 192 & 82.8 \\
\hline Quitted smoking & 4 & 1.7 \\
\hline \multicolumn{3}{|l|}{ Use of Alcohol } \\
\hline Regularly & 1 & 0.4 \\
\hline Sometimes & 11 & 4.7 \\
\hline Seldomly & 12 & 5.2 \\
\hline Never & 208 & 89.7 \\
\hline \multicolumn{3}{|l|}{$\begin{array}{c}\text { Presence of Constipation at that } \\
\text { Time }\end{array}$} \\
\hline Yes & 29 & 12.5 \\
\hline No & 203 & 87.5 \\
\hline \multicolumn{3}{|l|}{ Experience of Constipation Before } \\
\hline Yes & 180 & 77.6 \\
\hline No & 52 & 22.4 \\
\hline
\end{tabular}

( ${ }^{*}$ Health problems: Asthma; anemia; renal failure; epilepsy; allergy; scoliosis; arrhythmia; gastritis) 
It was observed that $90.1 \%$ of the students had no health problem and the students who had health problems suffered from asthma, anemia, renal failure, epilepsy, allergy, scoliosis, arrythmia, and gastritis. It was also determined that majority of the students did not use cigarettes (82.8\%) and alcohol (89.7\%) (Table 1). While $87.5 \%$ of the students stated that they had no constipation during the study, $77.6 \%$ stated that they experienced constipation before. The mean score obtained from the Constipation Assestment Scale was determined as $2.91 \pm 3.18$ (Table 1 ).

Table 2 shows the interventions used by the students to prevent or manage their own constipation and to what extent they found these interventions effective. While $92.1 \%$ of the students stated that pulpy foods were effective in constipation management; $93.8 \%$ stated that at least 2 liters of fluid consumption a day was effective. While $91.5 \%$ of the students stated that walking was an effective intervention; 83.8\% stated that drinking warm water half an hour before breakfast was effective (Table 2). As a result of the statistical analysis, it was seen that the female students had significantly higher total scores of CAS than the male students ( $t=3.38$; $p=0.001)$. It was also seen that the students who stated that they had constipation at that time had significantly higher total scores of CAS $(\mathrm{t}=8.51$; $\mathrm{p}<0.0001$ ). The students who stated that they had no constipation at that time stated that they consumed pulpy foods and this was effective ( $\left.\chi^{2}=10.99 ; \mathrm{p}=0.001\right)$. The students who stated that they had no constipation at that time expressed that they had at least 2 liters of water a day and this was effective $\left(\chi^{2}=15.89 ; \mathrm{p}<0.001\right)$.

Table 2: Interventions used by the students for their own constipation experiences and effectiveness of these interventions.

\begin{tabular}{|c|c|c|c|c|c|}
\hline \multirow{2}{*}{ Intervention Used } & \multicolumn{2}{|c|}{ Effective } & \multicolumn{2}{|c|}{ Ineffective } & \multirow{2}{*}{$\mathbf{P}$} \\
\hline & $\%$ & $\mathbf{n}$ & $\%$ & $\mathbf{n}$ & \\
\hline I abundantly consume pulpy foods $(n=190)$ & 92.1 & 175 & 7.9 & 15 & 0.001 \\
\hline I drink at least 2 liters of water a day $(n=177)$ & 93.8 & 166 & 6.2 & 11 & $<0.001$ \\
\hline I take a walk $(n=177)$ & 91.5 & 162 & 8.5 & 15 & 0.026 \\
\hline I drink warm water half an hour before breakfast $(n=74)$ & 83.8 & 62 & 16.2 & 12 & 0.602 \\
\hline $\begin{array}{l}\text { I designate a regular time for evacuation and have an defecation around the } \\
\text { same time every day }(n=76)\end{array}$ & 82.9 & 63 & 17.1 & 13 & 0.333 \\
\hline I drink milk $(n=135)$ & 77.8 & 105 & 22.2 & 30 & 0.166 \\
\hline I consume yoghurt $(n=173)$ & 80.3 & 139 & 19.7 & 34 & 0.124 \\
\hline I consume kefir $(n=43)$ & 74.4 & 32 & 25.6 & 11 & 0.454 \\
\hline I consume yoghurt with probiotic $(n=44)$ & 75.0 & 33 & 25.0 & 11 & 0.699 \\
\hline I consume apricot juice or dried apricots $(n=172)$ & 89.5 & 154 & 10.5 & 18 & 0.170 \\
\hline I drink Turkish coffee $(n=160)$ & 70.0 & 112 & 30.0 & 48 & 0.049 \\
\hline I massage the lower abdominal area $(n=131)$ & 91.6 & 120 & 8.4 & 11 & 0.528 \\
\hline
\end{tabular}

\section{Discussion}

As the health team members of the future; nursing students are primarily required to realize the presence of constipation in themselves and find a solution [16]. Therefore, the study was conducted to determine the prevalence of constipation in nursing students and the effectiveness of nursing interventions used by them to manage constipation in their own lives. In the present study, $12.5 \%$ of the students stated that they had constipation during the study. On the other hand, $77.6 \%$ of the students stated that they experienced constipation before. Similarly, the mean score obtained from the Constipation Evaluation Scale was determined as $2.91 \pm 3.18$. When examining the results of population-based studies in Turkey; it has been seen that the prevalence of constipation varies between $22-40 \%$ [18]. Thus, the result of the present study supports the results of previous studies. As a result of the statistical analysis, it was seen that the female students had significantly higher total scores of CES than the male students. In a similar study conducted on nursing students, it was reported that female students experienced the problem of constipation more than male students and they had a lower life quality regarding constipation [19]. The studies $[6,12,20]$ and systematic reviews $[2,3,5,21]$ have reported that there is a strong correlation between the female gender and constipation. Thus, the determination of a correlation between the female gender and constipation in the present study can be assessed as an expected result. This result can be associated with hormonal changes of women, as well as behavioral factors and digestive disorders. In a study, the prevalence of constipation was reported to be $31.3 \%$ in intern nurses working in regular shifts and $61.2 \%$ in intern nurses working in irregular shifts. As a result of the statistical analysis, it was determined that irregular shifts, poor sleep and having a difficulty in falling asleep significantly posed a risk for functional constipation [22]. This shows that nursing students are at the risk of having constipation and they need to diagnose and evaluate constipation that they may have. As a matter of fact, in the present study, the students who stated that they had constipation at that time had significantly higher total scores of CES. This result showed that the students could evaluate their constipation. It is known that a diet containing sufficient fiber, appropriate fluid intake, exercise and regular defecation habits is effective on preventing constipation $[23,24]$. As a matter of fact, the studies have shown that fiber-rich nutrition reduces the frequency of constipation [23,24,25,26,27,28]. Similarly, in two studies conducted with students, it was similarly reported that students consuming high-fiber foods experienced constipation-related pain problems less $[18,19]$. In the present study, it was also seen that the students who stated that they had no constipation at the time of the study consumed pulpy foods. In addition, the students consuming 
pulpy foods stated that the aforesaid nursing intervention was effective on preventing constipation $[p=0.001]$. Thus, it is thought that providing our patients suffering from constipation with a fiber-rich nutrition as a nursing intervention will be an effective intervention. It was determined that the students who stated that they had no constipation during the study drank at least 2 liters of water a day. The students consuming 2 liters of water a day stated that it was effective on preventing constipation [ $p<0.001]$. In their study, Annells \& Koch reported that an increase in fluid intake did not cause a distinct change in defecation [29]. In other studies, it was similarly seen that individuals adopting regular exercise habits and increasing fluid intake and fiber consumption experienced constipation less frequently [25,30,31].

\section{Conclusion}

As a consequence, this study showed that consumption of pulpy nutrients and 2 liters of water a day and exercise were an effective nursing intervention for the management of constipation.

\section{Acknowledgement}

None.

\section{Conflict of Interest}

No Conflict of Interest.

\section{References}

1. Johanson JF, Sonnenberg A, Koch TR (1998) Clinical epidemiology of chronic constipation. J Clin Gastroenterol 11(5): 525-536.

2. Schmidt FMQ, Santos VLCG (2014) Prevalence of constipation in the general adult population: an integrative review. J Wound Ostomy Continence Nurs 41(1): 70-76.

3. Suares NC, Ford AC (2011) Prevalence of, and risk factors for, chronic idiopathic constipation in the community: systematic review and metaanalysis. Am J Gastroenterol 106(9): 1582-1591.

4. Wasserman MS, Francisconi C, Olden K, Paíz LA, Bustos-Fernández L, et al. (2008) The Latin-American Consensus on Chronic Constipation. Gastroenterol Hepatol 31(2): 59-74.

5. Peppas G, Alexiou VG, Mourtzoukou E, Falagas ME (2008) Epidemiology of constipation in Europe and Oceania: a systematic review. BMC Gastroenterol 8: 5.

6. Schmidt FMQ Santos VLCG, Domansky RC, Barros E, Bandeira MA, et al. (2015) Prevalence of self-reported constipation in adults from the general population. Rev Esc Enferm USP 49(3): 440-449

7. Uz B, Türkay C, Bavbek N (2006) Konstipasyon saptanan olgularımızın değerlendirilmesi. Akademik Gastroenteroloji Dergisi 5: 56-59.

8. Kasap E, Bor S (2006) Fonksiyonel barsak hastalığı prevalansı. Güncel Gastroenteroloji 10: 165-168.

9. Papatheodoridis GV, Vlachogiannakos J, Karaitianos I, Karamanolis DG (2010) A Greek survey of community prevalence and characteristics of constipation. European Journal of Gastroenterology \& Hepatology 22(3): 354-360.

10. Peppas G, Alexiou VG, Mourtzoukou E, Falagas ME (2008) Epidemiology of constipation in Europe and Oceania: A systematic review. review. BMC Gastroenterol 8(5).

11. Woolery M, Wieland H, Jarosinski P, Corey B, Wallen GR, et al. (2006) A constipation assessment scale for use in pediatric oncology. Journal of Pediatric Oncology Nursing 23(2): 65-74.
12. Woodward S (2012) Assessment and management of constipation in older people. Nurs Older People 24(5): 21-26.

13. Ayaz S, Tezcan S, Akıncı F (2005) Hemşirelik yüksekokulu öğrencilerinin sağlığı geliştirme davranışları. Cumhuriyet Üniversitesi Hemşirelik Yüksekokulu Dergisi 9(2): 26-34.

14. Çelik OG, Malak TA, Bektaş M, Yllmaz D, Yümer AS (2009) Sağlık yüksekokulu öğrencilerinin sağlığı geliştirme davranışlarını etkileyen etmenlerin incelenmesi. Anatol J Clin Investig 3(3): 164-169.

15. Özkan S, Yllmaz E (2008) Hastanede çalışan hemşirelerin sağlıklı yaşam biçimi davranışları. Fırat Sağlı Hizmetleri Dergisi 3 (7): 89-104.

16. Uygur E, Kaya N, Kaya H, Karaman N (2008) Bir devlet hastanesinde çalışan hemşirelerin sağlık ekibi hizmeti anlayışları ve yaşanan sorunlar. İstanbul Üniversitesi Florence Nightingale Hemşirelik Yüksekokulu Dergisi 16(62): 102-113.

17. Demir Dogan M, Aktuğ C (2017) Validity And Reliability Of The Turkish Version Of Constipation Assessment Scale In Nursing Students. Euras J Fam Med 6(2): 72-76.

18. Uysal N, Khorshid L, Eşer İ (2010) The identification of constipation problem in healthy young individuals. TAF Prev Med Bull 9: 127-137.

19. Turan N, Kaya N, Kaya H, Öztürk A, Eskimez Z, et al. (2011) Hemşirelik Öğrencilerinin Bazı Değişkenler Açısından Konstipasyon Sorunları. İ.Ü.F.N. Hem. Derg 19(3): 168-178.

20. Garrigues V, Galvez C, Ortiz V, Ponce M, Nos P, et al. (2004) Prevalence of constipation: agreement among several criteria and evaluation of the diagnostic accuracy of qualifying symptoms and self-reported definition in a population-based survey in Spain. Am J Epidemiol 159(5): 520-526.

21. Higgins PD, Johanson JF (2004) Epidemiology of constipation in North America: a systematic review. Am J Gastroenterol 99(4): 750-759.

22. Ebrahim A, Fredericks S (2017) Working irregular shift patterns is associated with functional constipation among healthy trainee nurses. Gastroenterology Insights 8(1): 7229.

23. Tack J, Müller Lissner S, Stanghellini V, et al. (2011) Diagnosis and treatment of chronic constipation-A European perspective. Neurogastroenterology and Motility 23(8): 697-710.

24. Ternent CA, Bastawrous AL, Morin NA, Ellis CN, Hyman NH, et al.(2007) Practice parameters for the evaluation and management of constipation. Diseases of the Colon and Rectum 50(12): 2013-2022.

25. Dukas L, Willett WC, Giovannucci EL (2003) Association between physical activity, fiber intake, and other lifestyle variables and constipation in a study of women. Am J Gastroenterol 98(80): 1790-1796.

26. Ostaszkiewicz J, Hornby L, Millar L, Ockerby C (2010) The effects of conservative treatment for constipation on symptom severity and quality of life in community-dwelling adults. Journal of Wound, Ostomy, and Continence Nursing 37(2): 193-198.

27. Garrigues V, Gálvez C, Ortiz V, Ponce M, Nos P, et al. (2004) Prevalence of constipation: Agreement among several criteria and evaluation of the diagnostic accuracy of qualifying symptoms and self-reported definition in a populationbased survey in Spain. American Journal of Epidemiology 159(5): 520-526.

28. Gallegos-Orozco JF, Foxx-Orenstein AE, Sterler SM, Stoa JM (2012) Chronic constipation in the elderly. American Journal of Gastroenterology 107: $18-25$.

29. Annells M, Koch T (2003) Constipation and the preached trio: Diet, fluid intake, exercise. International Journal of Nursing Studies 40(8): 843-852.

30. Bosaeus I (2004) Fiber effects on intestinal functions (diarrhoea, constipation and irritable bowel syndrome). Clinical Nutrition Supplements 1: 33-38.

31. Hsieh C (2005) Treatment of constipation in older adults. American Family Physician 72(11): 2277-2284. 